\title{
Geotechnical properties of sandy clayey soil contaminated with lead and zinc
}

\author{
Alireza Negahdar ${ }^{1}\left[\right.$ Minoo Nikghalbpour ${ }^{1}$
}

Received: 26 January 2020 / Accepted: 19 June 2020 / Published online: 4 July 2020

(c) Springer Nature Switzerland AG 2020

\begin{abstract}
Previous studies have shown that pore fluid influences the geotechnical properties of soils. The aim of this paper is to investigate the effects of various concentrations of lead nitrate and zinc nitrate hexahydrate heavy metals in pore fluid on geotechnical properties of kaolinite-sand mixtures based on laboratory tests. Remolded samples of kaolinite-sand mixed with 5 and $25 \mathrm{cmol} / \mathrm{kg}$-soil concentrations of $\mathrm{Pb}\left(\mathrm{NO}_{3}\right)_{2}$ and $\mathrm{Zn}\left(\mathrm{NO}_{3}\right)_{2} \cdot 6 \mathrm{H}_{2} \mathrm{O}$ solutions were prepared. One-dimensional consolidation tests, direct shear tests, unconfined compression tests, consistency tests, sediment tests, adsorption tests, and $\mathrm{X}$-ray diffraction tests were conducted on samples to investigate the changes in geotechnical properties of samples in the presence of heavy metals in pore fluid. The results indicate that the presence of $\mathrm{Pb}$ (II) and $\mathrm{Zn}$ (II) would decrease the initial void ratio and sedimentation of samples which is attributed to the noticeable changes in soil microstructure. With increasing $\mathrm{Pb}$ (II) concentration from 0 to $25 \mathrm{cmol} / \mathrm{kg}$-soil, the void ratio of kaolinite containing 10, 25 and $40 \%$ sand decreased 18, 24 and $32 \%$ respectively. In addition, the reduction rates in similar samples containing $\mathrm{Zn}$ (II) were 14, 19 and $23 \%$. The liquid limit of samples also decreased when the concentration of heavy metals increased to $25 \mathrm{cmol} / \mathrm{kg}$-soil. The reduction in liquid limit was $21 \%, 15 \%$ and $14 \%$ for $\mathrm{Pb}(\mathrm{II})$ and 16,12 and $7 \%$ in the presence of $\mathrm{Z}$ (II) for samples with 10,25 and $40 \%$ of sand respectively. Significant decrease in the amount of cohesion also observed according to the test results. In the ratio of $40 \%$ sand the cohesion decreases $51 \%$ and $24 \%$ for $\mathrm{Pb}$ (II) and $\mathrm{Zn}$ (II) when the concentration of heavy metal increased from 0 to $25 \mathrm{cmol} / \mathrm{kg}$-soil. The results of unconfined compression tests show that there is noticeable reduction up to $52 \%$ due to $\mathrm{Pb}$ (II) with the concentration of $25 \mathrm{cmol} / \mathrm{kg}$-soil in the ration of $60 \%$ kaolinite and $40 \%$ sand.
\end{abstract}

Keywords Sandy clay soil · Heavy metal contaminant · Consolidation properties $\cdot$ Shear strength parameters · Atterberg limits

$\begin{array}{ll}\text { Abbreviations } \\ \mathrm{cmol} & \text { Centimole } \\ \mathrm{cc} & \text { Cubic centimetre } \\ \mathrm{g} & \text { Gram } \\ \mathrm{kg} & \text { Kilogram } \\ \mathrm{kPa} & \text { Kilo Pascal_kilo Newton to Square meter } \\ \mathrm{min} & \text { Minute } \\ \mathrm{mm} & \text { Millimeter } \\ \mathrm{m}^{2} & \text { Square meter } \\ \mathrm{s} & \text { Second }\end{array}$

\section{Introduction}

The rapid development of industry and human activities in urban areas led to an increase in the concentration of heavy metals in soil layers [1, 2]. Some frequent heavy metal contaminants found in soil included $\mathrm{Cr}, \mathrm{Cu}, \mathrm{Pb}(\mathrm{II})$, and $\mathrm{Zn}$ (II) $[1,3]$. Clay minerals adsorb all or parts of the hazardous materials present in leaked leachate. These minerals exchange interlayer cations with other metal cations $[1,4,5]$. This ability restricts the migration of contaminants into groundwater [3].

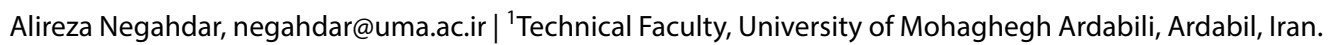


Numerous studies have been conducted to investigate the effect of pore fluid chemistry on geotechnical properties of soil clays [6-11]. The results approved that the compressibility of clays depends not only on the mechanical properties of clay minerals but also on the physicochemical factors of ions in the pore fluid [12]. Ouhadi et al. [13] stated that macrostructure characteristics were influenced by microstructure and the permeability coefficient depended on electrolytic specifications for pore water. The negative electric charges on clay particles adsorb dissolved cations in the surrounding pore fluid by the surface of clay particles [14]. The effect of heavy metals on the geotechnical and mechanical properties of clay have been investigated by many researchers $[6,15-24]$. The results imply that adsorption of heavy metal contaminants by clay soil results in decreasing the $\mathrm{pH}$ soil [25]. The reduction in $\mathrm{pH}$ could result in neutralization of some parts of the charges on clay surfaces and declines of the repulsion force, thus the particles become closer to each other $[25,26]$. Adsorption of heavy metal cations by kaolinite results in reducing the thickness of the double layer, thus reducing repulsion forces and caused the flocculated structure [24]. The development of a flocculated structure causes a reduction of plastic properties and increased permeability [27]. In addition, an extensive increase in hydraulic conductivity in bentonite and soil composition occurs at the presence of heavy metals [28]. Investigate the geotechnical properties of Kaolinite using $\mathrm{NaOH}$ shown that the liquid limit of soil samples increases with the increase in alkali concentration due to the formation of a swelling compound [29]. Karkush et al. [30] studied the effect of four types of contamination including Kerosene, ammonium hydroxide, lead nitrate and cooper sulphate on clayey soil. The results of the laboratory tests on samples showed that the contaminations have significant effect on physical, chemical and mechanical properties of soil samples. The effect depended on the type and percentage of contaminate in the soil. Generally according to their results kerosene and ammonium hydroxide make the particles finer and the other contaminants make the particles coarser compared to its natural properties [30]. The results of studies showed that in addition to the concentration of contamination, the curing days are also influence the geotechnical properties of clayey soil [31].

According to the findings of Karkush et al. [11] the strength parameters including cohesion and angle of internal reduce with increasing in contamination concentration while the initial void t-ratio compression indexes increased.

Among different types of clay minerals, the use of kaolinite as a natural absorbent is becoming popular due to its low cost and decent capability in adsorption of heavy metals like $\mathrm{Pb}$ (II), $\mathrm{Cu}(\mathrm{II}), \mathrm{Ni}$ (II) and $\mathrm{Zn}$ (II) supposed to wastewater [32]. The lack of access to suitable sources of pure clay soil along with other problems regarding the usage of compressed clay landfills including insufficient strength and formation of crack due to the change in the moisture content, have caused the tendency in the application of clay soils and sandy clay in some projects [33-36]. Ohadi et al. [37] studied the effect of $\mathrm{Pb}(\mathrm{II})$ and $\mathrm{Zn}$ (II) on the liquid limit of the sand-clay mixtures. Their results suggested that generally with the increase in the concentration of the contaminants, the soil liquid limit decreased [37]. Investigating the effect of pore fluid dielectric on kaolinite samples results in increased shear strength values and decreased compression and swelling index [38]. The results of evaluating the different concentrations of $\mathrm{CuCl}_{2}$ solution on the strength properties of kaolinite showed that the cohesion and internal friction of samples decreased gradually by the increase of ion concentration [24]. Sedimentation behavior of clayey soil were interpreted by performing sedimentation tests on contaminated samples in the prospective of soil fabric [39, 40].

Negahdar et al. evaluated the effect of lead nitrate and Zinc nitrate contamination on sandy clay. According to the results of the direct shear test when contaminants of heavy metals increased, soil cohesion decreased by up to $23 \%$ for $\mathrm{Zn}$ (II) and up to $51 \%$ for $\mathrm{Pb}$ (II). However, the internal friction angle of the samples was not affected by the presence of heavy metal contaminants [41].

As mentioned, wide studies have been conducted to evaluate the influence of heavy metal contaminants on the geotechnical properties of clay and also to assess the geotechnical properties of clay-sand mixtures [28, $34,35,42,43]$. However, few studies considered the alteration of these parameters in kaolinite-sand mixtures contaminated by heavy metals. Therefore, in the current study sandy kaolinite were chosen as the soil mixture.

In addition in the literature review, the researchers investigated the influence of a wide range of heavy metals in aqueous solution on different kinds of kaolinite [24-26, $32,44]$. Among the heavy metals found in wastewater due to the high frequency of the $\mathrm{Pb}$ nitrate and $\mathrm{Zn}$ nitrate, these materials were chosen in this research [45]. The present study tries to evaluate changes in the geotechnical properties of sandy kaolinite influenced by $\mathrm{Pb}$ nitrate and Zn nitrate contamination through 1-D consolidation tests, direct shear tests, unconfined compression tests, the consistency tests, the sedimentation test, the adsorption test, and XRD tests. All tests were conducted on remolded samples mixed with contaminated solution of 5 and $25 \mathrm{cmol} /$ kg-soil concentrations of $\mathrm{Pb}\left(\mathrm{NO}_{3}\right)_{2}$ and $\mathrm{Zn}\left(\mathrm{NO}_{3}\right)_{2} \cdot 6 \mathrm{H}_{2} \mathrm{O}$. Considering the cation-exchange capacity, CEC of kaolinite 3-15 cmol/ $\mathrm{kg}$-soil, two values of concentration was considered to be greater than the CEC threshold of kaolinite $[24,46]$. The results obtained in this study provide the 
Table 1 The primary physical and chemical characteristics of kaolinite

\begin{tabular}{ll}
\hline Property evaluated & The measured values \\
\hline Soil classification & $\mathrm{CL}$ \\
Liquid limit, \% & 46 \\
P.I. \% & 20 \\
$\gamma_{\text {dmax }}\left(\mathrm{g} / \mathrm{cm}^{3}\right)$ & 1.96 \\
$\omega_{\text {opt }}(\%)$ & 17.5 \\
$\mathrm{pH}(1: 50$, soil-water $)$ & 8.9 \\
XRD analysis & Kaolinite, Quartz, Calcite \\
CEC (cmol/kg-soil) & 11.5 \\
Carbonate $(\%)$ & 4 \\
Sulphate content (\%) & 0 \\
Gs & 2.75 \\
\hline
\end{tabular}

initial data and information need to predict the behavior of kaolinite faced with wastewater in the nature.

\section{Material}

The Kaolinite used in this research was in the form of a white powder which was supplied by Iran's porcelain soil industries. Table 1 indicates the geotechnical properties as well as the chemical characteristics of the utilized kaolinite, which have been determined based on ASTM 2004 standard method [47]. CEC of kaolinite was determined according to $\mathrm{BaCl}_{2}$ replacement method [48]. XRD analysis was performed based on the method suggested by some researchers $[49,50]$. The $\mathrm{pH}$ of soil was measured in 1:10 soil solution. The carbonate content was determined by titration method [51]. Particle size distribution of kaolinite obtained from hydrometer tests is shown in Fig. 1. The sand used in this research belongs to ASTM-C778 classification and is $\mathrm{SiO}_{2}$ (Ottawa) silica sand. In the pure state, the percentage of silica in it is around $99.8 \%$. Its particles are round-shaped and a diameter of the particles varies between 0.595 and $1.18 \mathrm{~mm}$. Figure 2 shows the sieveanalysis graph of the used sand. Heavy metal solutions including $\mathrm{Pb}\left(\mathrm{NO}_{3}\right)_{2}$ and $\mathrm{Zn}\left(\mathrm{NO}_{3}\right)_{2} \cdot 6 \mathrm{H}_{2} \mathrm{O}$ were used in experiments.

\section{Methodology}

In order to examine the effect of heavy metal contaminants on geotechnical properties of sand-clay mixtures, the experiments of liquid limit determination, consolidation, and direct shear tests, unconfined compression tests were done on the samples according to ASTM D4318, ASTM D 2435, ASTM D 3080-90 standards ASTM D2166

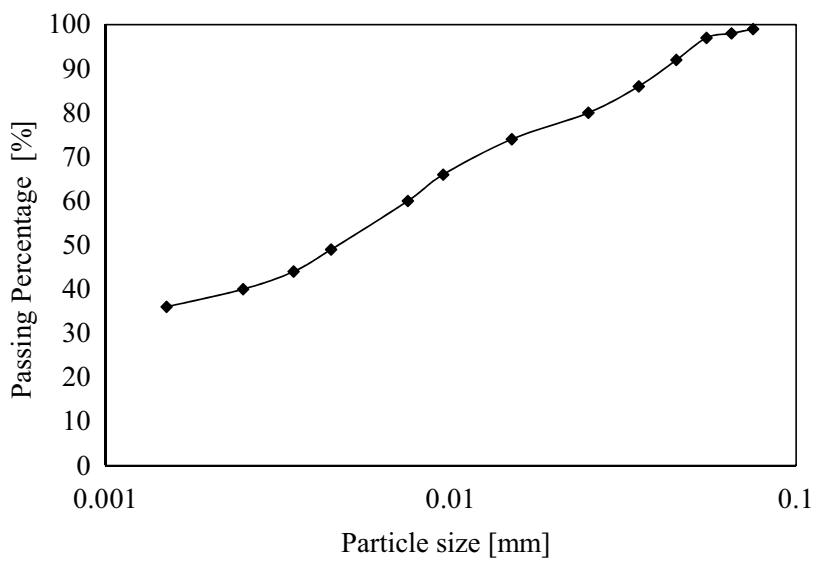

Fig. 1 Particle size distribution of kaolinite

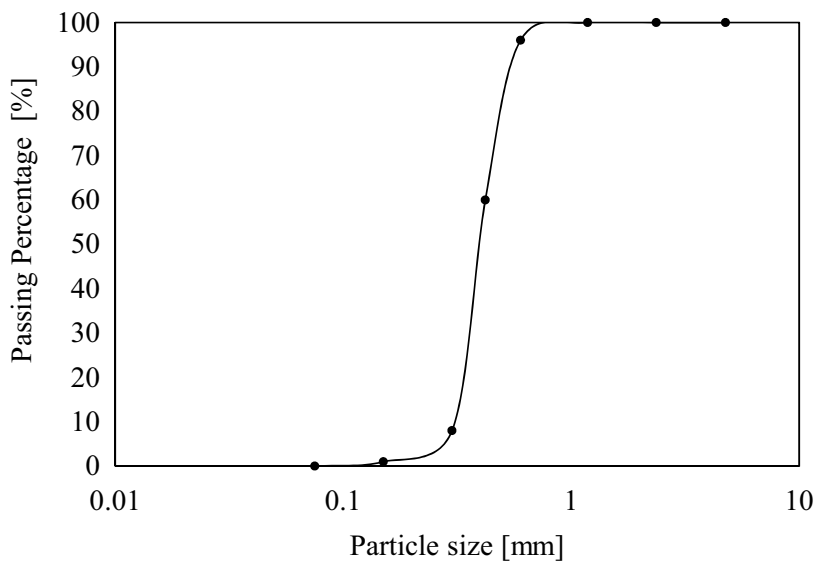

Fig. 2 Particle size distribution of sand

respectively [47]. The optimum moisture content and maximum dry density of each sample were determined in the standard proctor compaction test. Based on the results of standard proctor tests, direct shear test samples are prepared. Kaolinite-sand mixtures were prepared by a mixing oven dried kaolinite with oven dried percentages of 10,25 , and $40 \%$ sand. It should be noted that there are different preparation methods, suggested by innovative researchers. In this study, specimen preparation was performed according to Ouhadi and Yong [52]. In order to add the heavy metal contaminants to the soil samples, first, the solution of the contaminants was prepared for two concentrations of. 5 and $25 \mathrm{cmol} / \mathrm{kg}$-soil for each heavy metal. Then, the solution of the contaminant and soil was poured into plastic bottles with a 1:10 soil/solution ratio. Afterward, the samples were mixed with each other for 4 days and they were mixed by an electric shaker device for $2 \mathrm{~h}$ each day. Once they reached equilibrium, the samples were poured into glass Pyrexes and placed inside 
Fig. 3 Flow diagram of sample preparation for tests

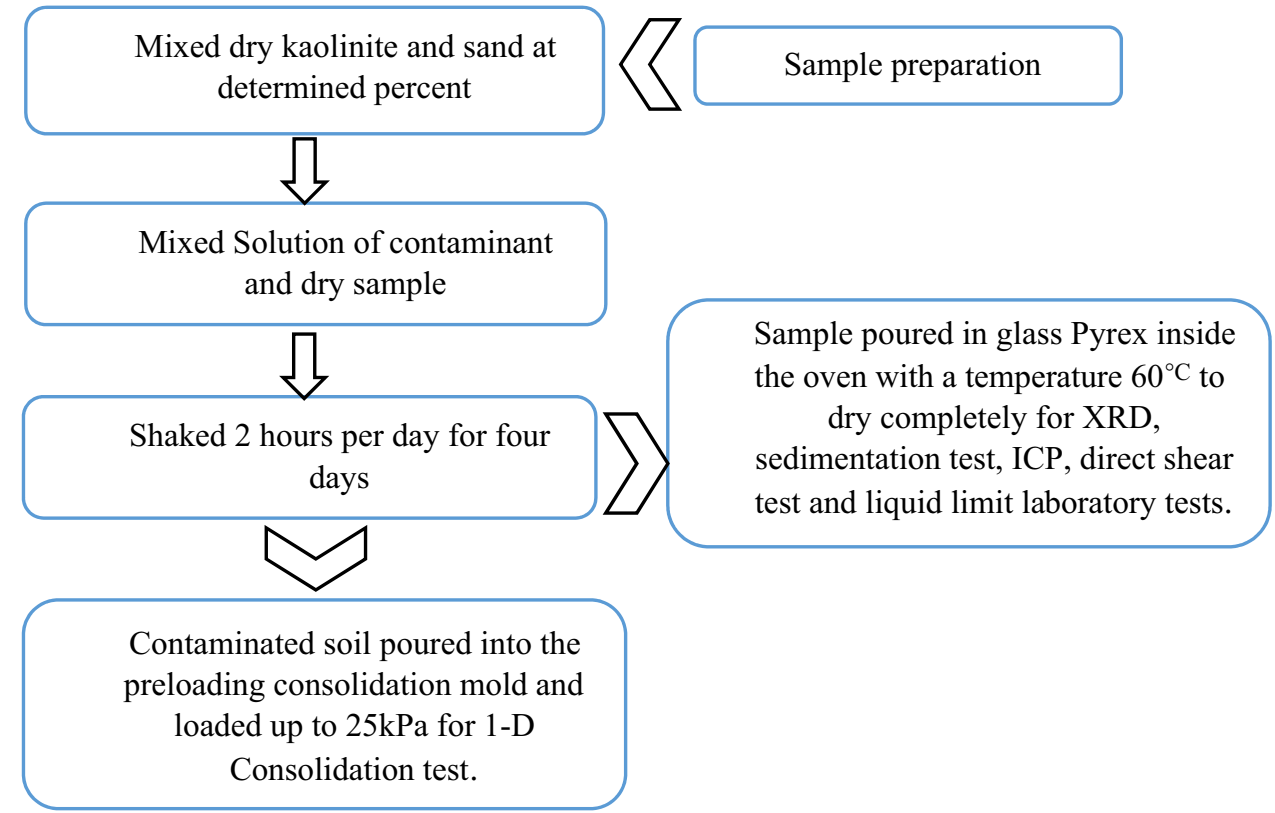

an oven with a temperature up to $60^{\circ} \mathrm{C}$ in order to dry completely. For the direct shear test, samples were placed and compacted in a shear test mold with $6 \mathrm{~cm}$ dimensions and $2.6 \mathrm{~cm}$ height and were loaded at the strain rate of $0.8 \mathrm{~mm} / \mathrm{min}$. The samples for unconfined compression tests were remolded with the maximum dry density standard dimensions of the test with optimum moisture content of the polluted soil. For preparing the sample for consolidation test contaminated soil was poured into preloading consolidation mold and loaded up to $25 \mathrm{kPa}$.

XRD has became one of the significant analytical method used in the qualitative study of clay minerals $[53,54]$. Thus, the mechanism of the microstructure status and its changes in kaolinite-sand mixtures in the presence of $\mathrm{Pb}(\mathrm{II})$ and $\mathrm{Zn}$ (II) was determined by XRD [50, 53]. Sedimentation tests were conducted to interpret the sedimentation behavior of contaminated samples $[39,55]$. Soil preparation sample for XRD included mixing $1 \mathrm{~g}$ of contaminated soil with $50 \mathrm{ml}$ of distilled deionized water for 4 days, vibrated $2 \mathrm{~h}$ each day by electrical vibration device. Then the samples are released for $24 \mathrm{~h}$ to reach the balance. Subsequently, the specimens were shaken for $30 \mathrm{~min}$, some of the suspension was removed by pasteurizing pipettes and put on a clean, dry for $24 \mathrm{~h}$.

Analysis characteristics of the pore water characteristics to determine the adsorbed cations of contaminated samples was done by ICP ${ }^{1}$-OES device provided by Tarbiat Modares University according to EPA ${ }^{2}$ guideline [56]. For this purpose, $1 \mathrm{~g}$ of soil specimen was subjected to the contaminant, was dried and passed through sieve No. 200. Then it was poured in a falcon tube and $10 \mathrm{ml}$ distilled water (1:10 ratio) was added to it. The samples were stored for 4 days and they were mixed by an electric shaker device for $2 \mathrm{~h}$ each day. Afterward, the samples were centrifuged at $4000 \mathrm{rpm}$ for $15 \mathrm{~min}$ in order to separate the liquid and solid phases. The contaminant concentration of the liquid phase was determined by the ICP device. In order to determine the total concentration of contaminants in soil soluble and exchangeable phases, $1 \mathrm{~g}$ of soil specimen subjected to contaminant was dried and passed through sieve \#200. Then, it was poured in a falcon tube and $10 \mathrm{mlBaCl}_{2}, 0.1$ molar solution (1:10 ratio) was added to it. The contaminant concentration of the liquid phase was determined as the previous test. Finally, the contaminant concentration adsorbed by soil was calculated from the difference between the two concentrations obtained above. The sample preparation chart is shown in Fig. 3.

\section{Results and discussion}

XRD tests were done in order to evaluate the microstructure characteristics of samples in kaolinite-sand mixtures at the presence of $\mathrm{Pb}$ (II) and $\mathrm{Zn}$ (II). The results are shown in Fig. $4 a$, $b$ for the samples contaminated with $\mathrm{Pb}$ (II) and $\mathrm{Zn}$ (II) respectively.

\footnotetext{
1 Inductively Coupled Plasma.

2 United States Environmental Protection Agency.
} 

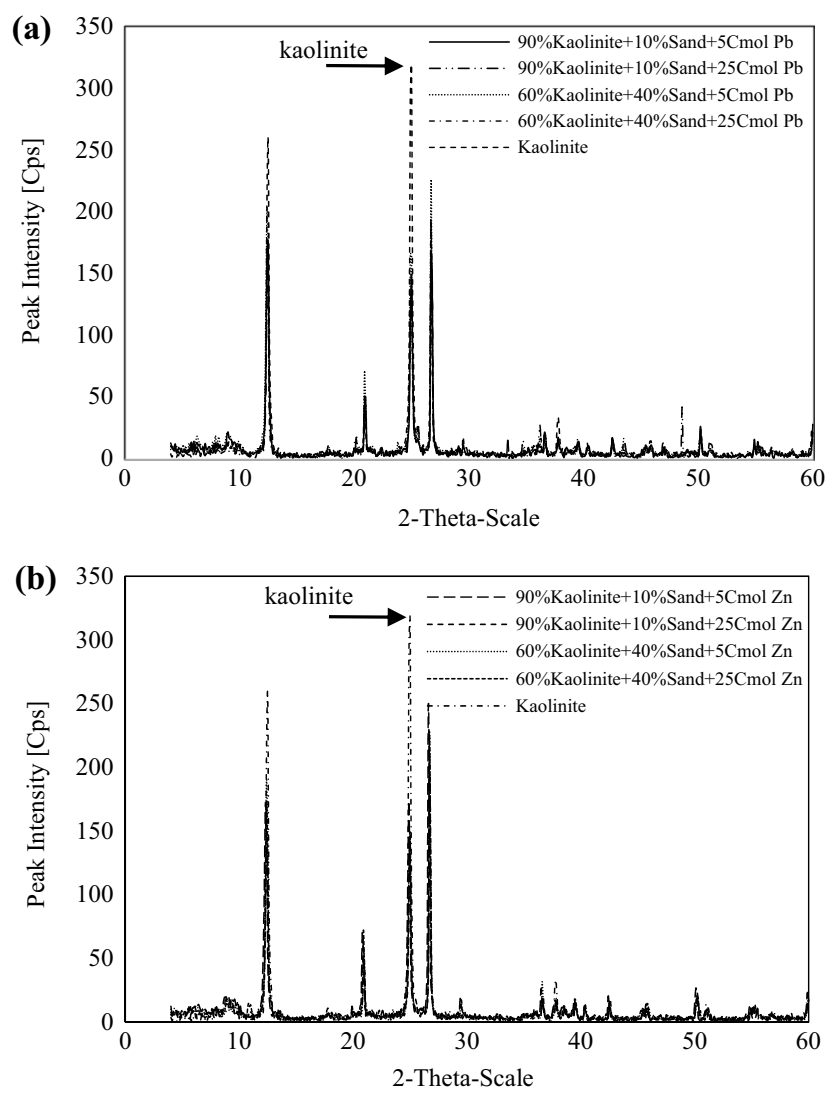

Fig. 4 XRD test results of kaolinite-sand mixtures at the presence of $\mathbf{a} \mathrm{Pb}(\mathrm{II})$ and $\mathbf{b} \mathrm{Zn}$

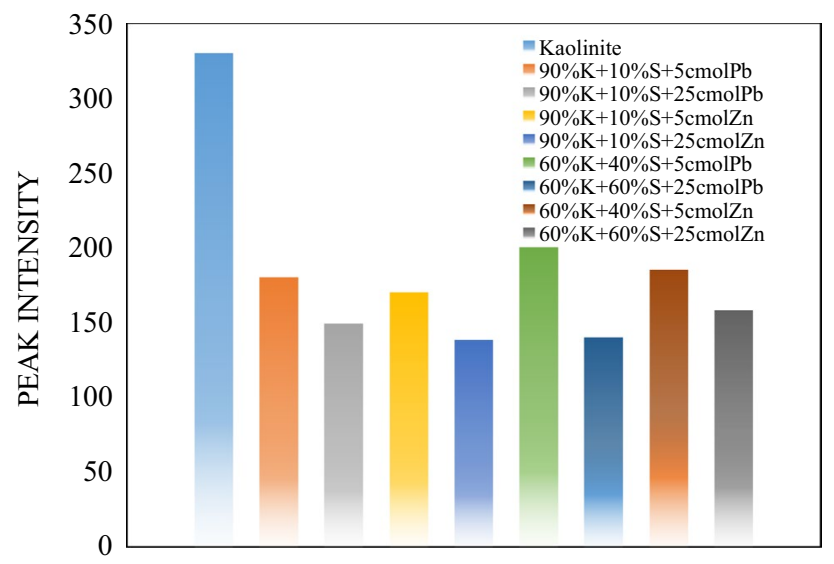

Fig. 5 The intensity of the main kaolinite peak $(7.13 \AA$ ) of pure kaolinite and kaolinite-sand mixtures at different concentration of $\mathrm{Pb}(\mathrm{II})$ and $\mathrm{Zn}$ (II) contamination

According to Fig. 4, the main kaolinite specimen has the most intense peak at 7.13 and $3.56 \AA$ that indicates the domination of kaolinite mineral. Therefore, the assessments were focused on this mineral. Figure 5 shows the changes in the main kaolinite peak (7.13 $\AA$ ) in specimens with the different sand percentages at the presence of contaminants.

In specimens with $90 \%$, kaolinite, 5 and $25 \mathrm{cmol} /$ $\mathrm{kg}$-soil $\mathrm{Pb}$ (II) reduced the peak intensity by 33 and $45 \%$, respectively, compared to pure kaolinite sample. These percentages were 36 and 48 for $\mathrm{Zn}$ (II) contamination. In specimens with $60 \%$ kaolinite, 5 and $25 \mathrm{cmol} / \mathrm{kg}$-soil $\mathrm{Pb}$ (II) reduced the peak intensity by 26 and $48 \%$, whereas 5 and $25 \mathrm{cmol} / \mathrm{kg}$-soil Zn(II) reduced the peak intensity by 31 and $42 \%$, respectively. Overall, the results show the reduction of kaolinite peak intensity with an increase in $\mathrm{Pb}$ (II) and Zn(II) contaminants concentration. It seems that increasing the heavy metal concentrations in soil samples could act in favor of attraction force on repulsion force in clay platelets and lead the soil structure flocculate.

For further examination of changes, the structure of kaolinite, a sedimentation test was performed on samples with different percentages of sand and in the presence of different concentrations of heavy metal contaminants. The results are shown in Fig. 6.

According to Fig. 6, with an increase in $\mathrm{Pb}$ (II) and $\mathrm{Zn}$ (II) concentration, sedimentation would increase as well which is consistent with XRD results. Gouy-Chapman's double layer theory, the thickness of a double layer, $\frac{1}{\hat{K}}$, is calculated by Eq. (1).

$\frac{1}{\hat{K}}=\left[\frac{\varepsilon_{0} D k T}{2 n_{0} v^{2} e^{2}}\right]^{1 / 2}$

In the Eq. (1), $\varepsilon_{0}$ is the dielectric constant of vacuum, $D$ is the dielectric constant of the fluid, $\mathrm{k}$ denotes Boltzmann constant $\left(1.38 \times 10^{-23} \mathrm{~J}^{-\mathrm{k}^{-1}}\right), \mathrm{T}$ is the temperature in terms of Kelvin degree, $n_{0}$ represents the electrolyte's concentration (ion $/ \mathrm{m}^{3}$ ), $e$ is the electric charge of the electron $\left(1.602 \times 10^{-19} \mathrm{C}\right)$, and $v$ is ion capacity.

The double-layer thickness is directly related to the square root of dielectric constant and temperature, while it is inversely related to valance and the square root of concentration. Hence, heavy metal contaminant $\mathrm{Pb}(\mathrm{II})$ and $\mathrm{Zn}$ (II) would decrease the double layer thickness around clay platelets. Also, the increase in the concentration of these contaminants would cause further reduction of double-layer thickness. In this case, the electric potential on the clay platelets would also decrease and change the soil structure in favor of a flocculated structure [52]. This confirms the decrease of kaolinite peak intensity in XRD test and the increase of samples sedimentation with an increase of contaminant concentration.

Figure 6 also suggests that in the sedimentation test, the effect of heavy metal contaminant $\mathrm{Pb}$ (II) is slightly higher than that of $\mathrm{Zn}(\mathrm{II})$. One of the superficial reactions of clay minerals is adsorption and the exchange of metal cations. The type and quantity of each mineral in clay soils 

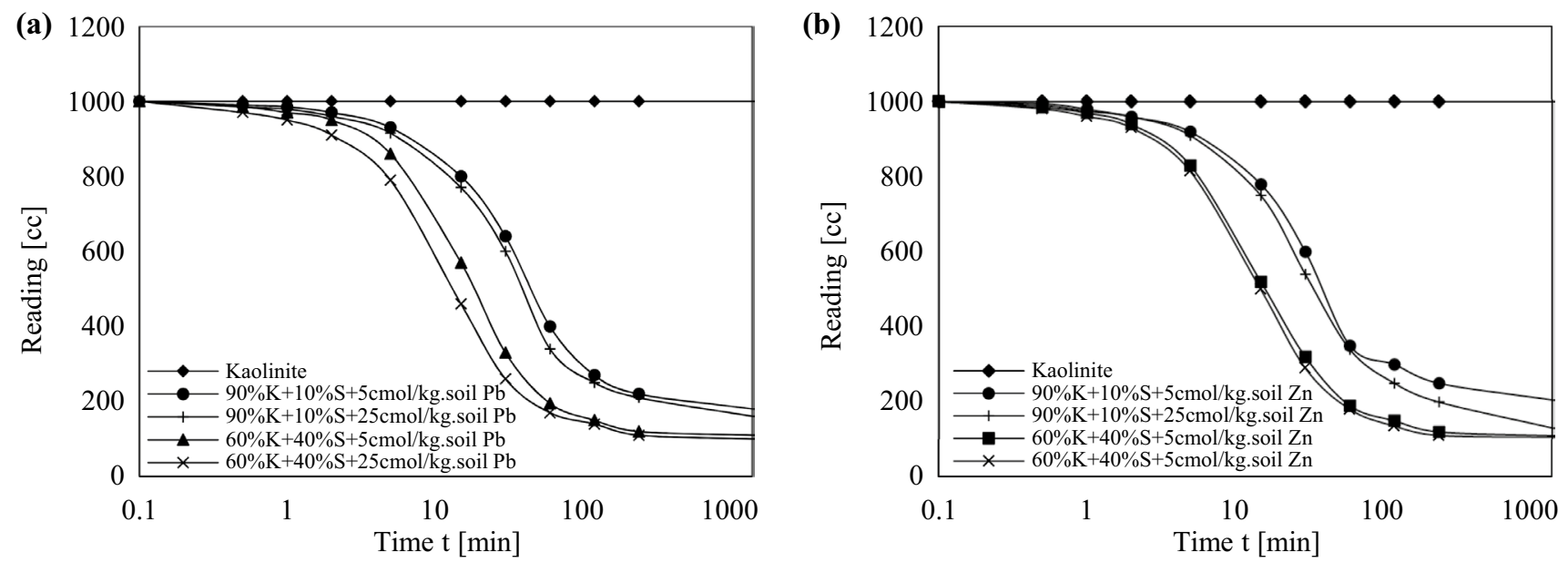

Fig. 6 Sedimentation test of specimens with different amount of sand and different concentration of a $\mathrm{Pb}$ (II) and $\mathbf{b} \mathrm{Zn}(\mathrm{II})$

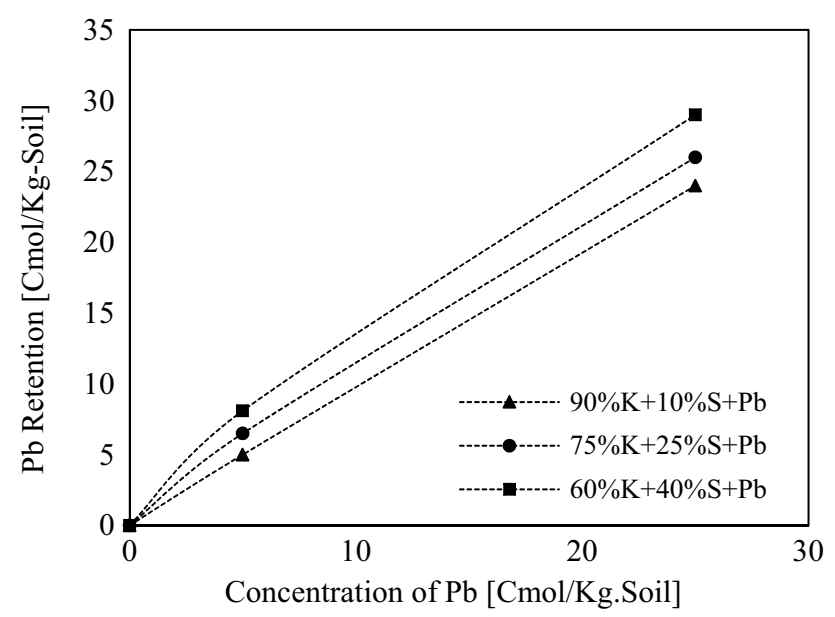

Fig. 7 The ability to retain $\mathrm{Pb}(\mathrm{II})$ heavy-metal contaminant by the kaolinite-sand mixture samples

have a significant effect on the interaction between soil and contaminants [57].

The ability of the kaolinite-sand mixture samples to retain the heavy metal contaminants of $\mathrm{Pb}$ (II) and $\mathrm{Zn}$ (II) is presented in Figs. 7 and 8.

The results obtained from investigation of the extent of retention of the $\mathrm{Pb}$ (II) and $\mathrm{Zn}$ (II) heavy-metal contaminants suggest that across all the samples and in the presence of both heavy metals, with an increase in the concentration of the contaminant, the extent of retention of kaolinite-sand mixture samples has also increased.

With the increase in the concentration of $\mathrm{Zn}$ (II) up to $25 \mathrm{cmol} / \mathrm{kg}$-soil, the kaolinite-sand mixture samples with sand percentages of 10,25 , and $40 \%$ show a retention ability of around 20, 22, and $25 \mathrm{cmol} / \mathrm{kg}$-soil for $\mathrm{Zn}$ (II).

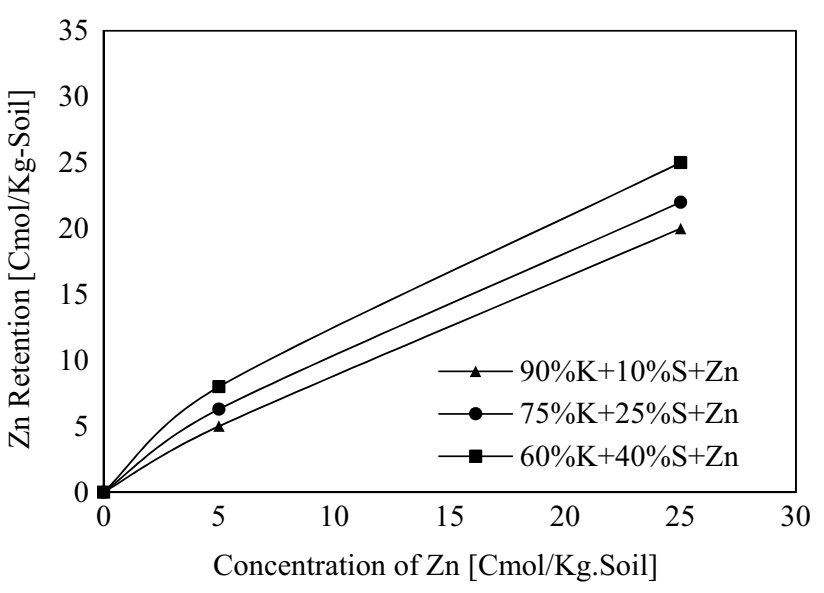

Fig. 8 The ability to retain $\mathrm{Zn}(\mathrm{II})$ heavy-metal contaminant by the kaolinite-sand mixture samples

However, the retention ability of $\mathrm{Pb}(\mathrm{II})$ for those samples is 24,26 , and $29 \mathrm{cmol} / \mathrm{kg}$-soil.

Based on the previous studies, the retention ability of soil is dependent on three major factors including CEC, the specific area, and the content of carbonate, which carbonate plays a more significant role than the two other factors [21].

As was mentioned previously, in the kaolinite $90 \%$-sand $10 \%$ mixture sample and at the $\mathrm{Pb}$ (II) concentration of 25 $\mathrm{cmol} / \mathrm{kg}$-soil, about $24 \mathrm{cmol} / \mathrm{kg}$-soil has been retained by the sample. In other words, if all exchange sites take part in the contaminant retention process, around $13 \mathrm{cmol} / \mathrm{kg}$-soil has been retained by other phases including carbonate, organic compounds, and hydroxides [58].

Another notable point that can be inferred from Figs. 7 and 8 is that the increase in the extent of contaminants retained by kaolinite-sand mixture samples is due to 


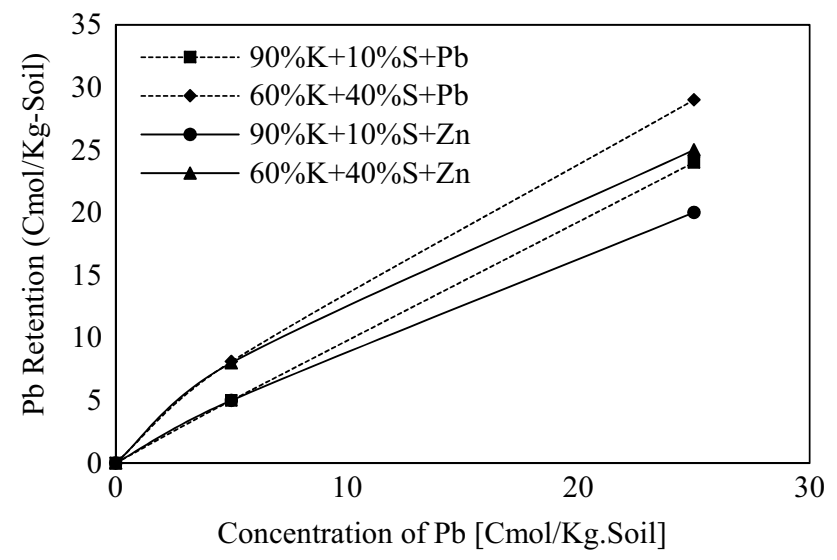

Fig. 9 Comparison retaining $\mathrm{Pb}$ (II) and $\mathrm{Zn}$ (II) heavy-metal contaminant by the kaolinite-sand mixture samples

the increase in their sand percentage. In other words, elevation of the share of sand in kaolinite-sand mixture result in increased extent of soil contamination retention, where in some cases the amount of adsorbed contaminant has been greater than the value of the input contaminant (the concentration of input contaminant which has been based on the total mass of the kaolinite-sand mixture). This can be attributed to the insignificant role of sand in the adsorption process of the contaminant. In other words, the increase in the quantitative share of sand (as it does not participate in the adsorption process of contaminants) has caused a lower volume of clay soil (kaolinite) to be exposed to heavy-metal contaminant at the constant concentration of the input contaminant (which has been calculated based on the total mass of the kaolinite-sand mixture), thereby causing elevation of soil adsorption.

Furthermore, comparison the retention results of $\mathrm{Pb}$ (II) and $\mathrm{Zn}(\mathrm{II})$ in samples shows the selective adsorption.

Figure 8 shows the capability of keeping $\mathrm{Pb}$ (II) and $\mathrm{Zn}$ (II) contaminants for two samples of kaolinite-sand mixtures with sand percentages of $10 \%$ and $40 \%$.

According to Fig. 9, it can be seen that the potential for retention of $\mathrm{Pb}$ (II) is higher than $\mathrm{Zn}$ (II). In addition, all specimens show a greater tendency to adsorb $\mathrm{Pb}$ (II) ions compared to $\mathrm{Zn}$ (II) ions. This behavior is known as the selective absorption in the retention of contaminants. In fact, the presence of carbonate enhance the buffering capacity of soil and provide higher retaining of heavy metal [58].

To further examine how the geotechnical characteristics of the specimens were changed, the Atterberg limit tests, consolidation test and unconfined compression tests were done on the specimens.

Figure 10 shows the liquid limit test results of specimens with different percentages of sand and different contamination concentration of $\mathrm{Pb}$ (II) and $\mathrm{Zn}$ (II). The concept of plasticity represents the ability of soil formability

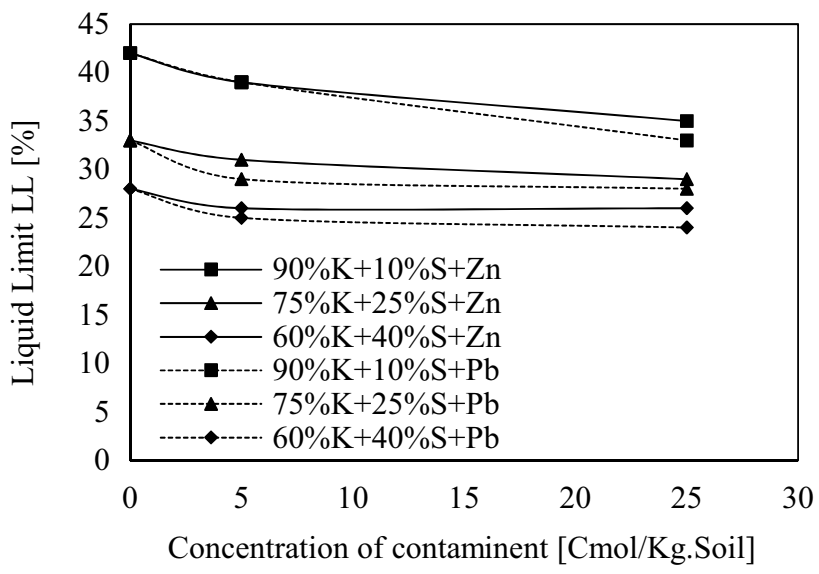

Fig. 10 The changes in the liquid limit of kaolinite-sand mixture samples versus different concentrations of $\mathrm{Pb}$ (II) and $\mathrm{Zn}$ (II)

without dissociation of particles, such that the main factor for soil plasticity is a result of clay flat particles being charged.

The results presented in Fig. 9 suggest that generally the liquid limit of the samples would reduce at the presence of $\mathrm{Pb}(\mathrm{II})$ and $\mathrm{Zn}(\mathrm{II})$ and a further reduction was observed with the increase in their concentration.

At $\mathrm{Zn}$ (II) concentration of $5 \mathrm{cmol} / \mathrm{kg}$-soil, the liquid limit of kaolinite-sand mixture samples with sand ratios of $10 \%, 25 \%$, and $40 \%$ has decreased almost equally by $3 \%$, whereas with the increase in the concentration of the contaminant by up to $25 \mathrm{cmol} / \mathrm{kg}$-soil the extent of changes has been 10,6 , and $1 \%$, respectively.

Considering $\mathrm{Pb}(\mathrm{II})$ at the concentration of $5 \mathrm{cmol} /$ $\mathrm{kg}$-soil, the liquid limit of the kaolinite-sand mixture samples with ratios of 10,25 and $40 \%$ of sand decreased by 7,11 and $12 \%$, respectively, while with the increase in the concentration of the contaminant up to $25 \mathrm{cmol} /$ $\mathrm{kg}$-soil, the extent of these changes has been 15, 4, and $3 \%$, respectively. The reduction of the liquid limit of samples in the presence of heavy metal contaminants can be attributed to the mechanism mentioned for the $X R D$ results. Based on the results of the XRD and sediment test, the presence of heavy metals in the soil and their adsorption by soil altered the structure of the soil from dispersed to flocculated, as a result of this alteration, the water absorption by clay loam and the limit of the samples were reduced.

The reduction in the liquid limit of the samples in the presence of $\mathrm{Pb}$ (II) and $\mathrm{Zn}$ (II) can be attributed to the two following mechanisms:

The first mechanism suggests that the presence of heavy metals in water and soil system causes the $\mathrm{pH}$ of this system to decrease significantly due to the hydrolysis reaction of heavy metals [3]. The decrease in the soil's pH 
causes a reduction in the thickness of the double layer around the clay platelets and development of a tangled (flocculated) structure in the soil that results in lower specific surface area in clay platelets. Therefore, the water adsorption level of clay platelets and the liquid limit of the samples would decrease.

Considering the Gouy-Chapman double layer theory as well as the Eq. (1) presented for it, the second mechanism suggests that the reduction in the thickness of the double layer of clay platelets can be a result of the presence of heavy metal contaminants. Therefore, with the increase in the concentration of heavy metal contaminants, the thickness of the double layer around the clay platelets declines. This signifies the accumulation of water molecules and ions in the vicinity of clay mineral and reduction in the number of water molecules in the double layer. In this way, considering the reduced tendency of kaolinite for water adsorption, the liquid limit of the kaolinite-sand mixture samples also declines with the increase in the concentration of heavy metal contaminants.

Comparison of $\mathrm{Zn}(\mathrm{II})$ and $\mathrm{Pb}$ (II) effect on the liquid limit of the samples, Fig. 10 also suggests that at certain concentrations, $\mathrm{Pb}$ (II) has a greater effect than $\mathrm{Zn}$ (II). This can be attributed to the greater tendency of kaolinite to $\mathrm{Pb}$ (II) adsorption than $\mathrm{Zn}$ (II).

Low variation of the liquid limit of samples in the presence of various concentrations of contaminations can be found according to the results of research carried out by Chen et al., 2000. In their study, the effect of electrolyte solutions on the properties of two types of pure kaolinite and composite $70 \%$ Kaolinite with $30 \%$ sand. The researchers found that the calcium chloride solution had no significant effect on the psychological limit the effect of electrolyte solutions on the properties of two types of pure kaolinite and composite $70 \%$ Kaolinite with $30 \%$ sand [59].

In the following, the one-dimensional consolidation test was carried out on samples to investigate the effect of $\mathrm{Pb}$ (II) and $\mathrm{Zn}$ (II) heavy metal contamination on the compressibility and consolidation behavior of mixtures of kaolinite-sand. The results of this experiment are shown in Fig. 11.

It is notable that the initial void ratio of each sample was achieved with preloading of a solution containing a mixture of kaolinite-sand and contaminants in especial cells in constant conditions. Considering the constant procedure of preloading on samples, void ratio changes should be due to changes in samples such as kaolinite to sand proportion and heavy metal concentration.

Figure 11 shows that the decline of the kaolinite portion could reduce the initial void ratio and settlement of samples that were expected as the sand portion is unable to consolidate.

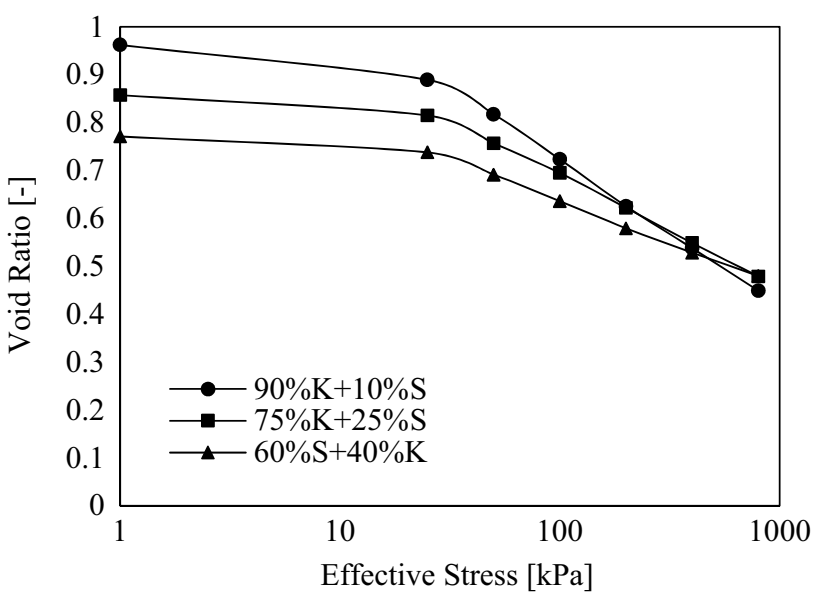

Fig. 11 Variation of void ratio versus effective stress for kaolinitesand samples

Figure 12 exhibits the consolidation curve of kaolinite-sand samples. Generally, results indicate that the void ratio and settlement of samples decrease as contaminant concentration increases. $\mathrm{As} \mathrm{Pb}$ (II) concentration increased from 0 to $25 \mathrm{cmol} / \mathrm{kg}$-soil, initial void ratio of kaolinite-sand samples with sand portion of 10, 25 and $40 \%$ decreased by 18,24 and $32 \%$, respectively. In similar samples with $\mathrm{Zn}$ (II) contamination, the reduction values were 14,19 and $23 \%$.

According to Gouy-Chapman's double layer theory and Eq. (1), an increase of heavy metal concentration would result in narrowing the double layer which could lead nitrate to the accumulation of ions and water molecules around clay mineral and reduction of water molecules number in the double layer. The reduction of water absorption of clay mineral could decrease the consolidation settlement. Due to hydrolysis reactions, heavy metals could cause a significant drop in $\mathrm{pH}$ in the soil-water system [60]. Soil pH drop, along with narrowing the double layer around clay platelets, could lead nitrate to flocculated structure formation that has been confirmed in XRD and settlement tests. In this way, settlement under pre-consolidation stress would increase and as a result void ratio would decrease.

Figure 12 also shows that the influence of pore fluid properties on consolidation behavior would decreased at a higher loading rate. In other words, at a high loading rate, mechanical properties would be dominant and physicochemical properties on electrolytes have a negligible impact of soil behavior [52].

Figure 13 compares the influence of $\mathrm{Pb}$ (II) and $\mathrm{Zn}$ (II) on the consolidation behavior of samples. Results indicate that in certain concentrations $\mathrm{Pb}$ (II) has a more significant effect than Zn(II) on the consolidation behavior. It could 

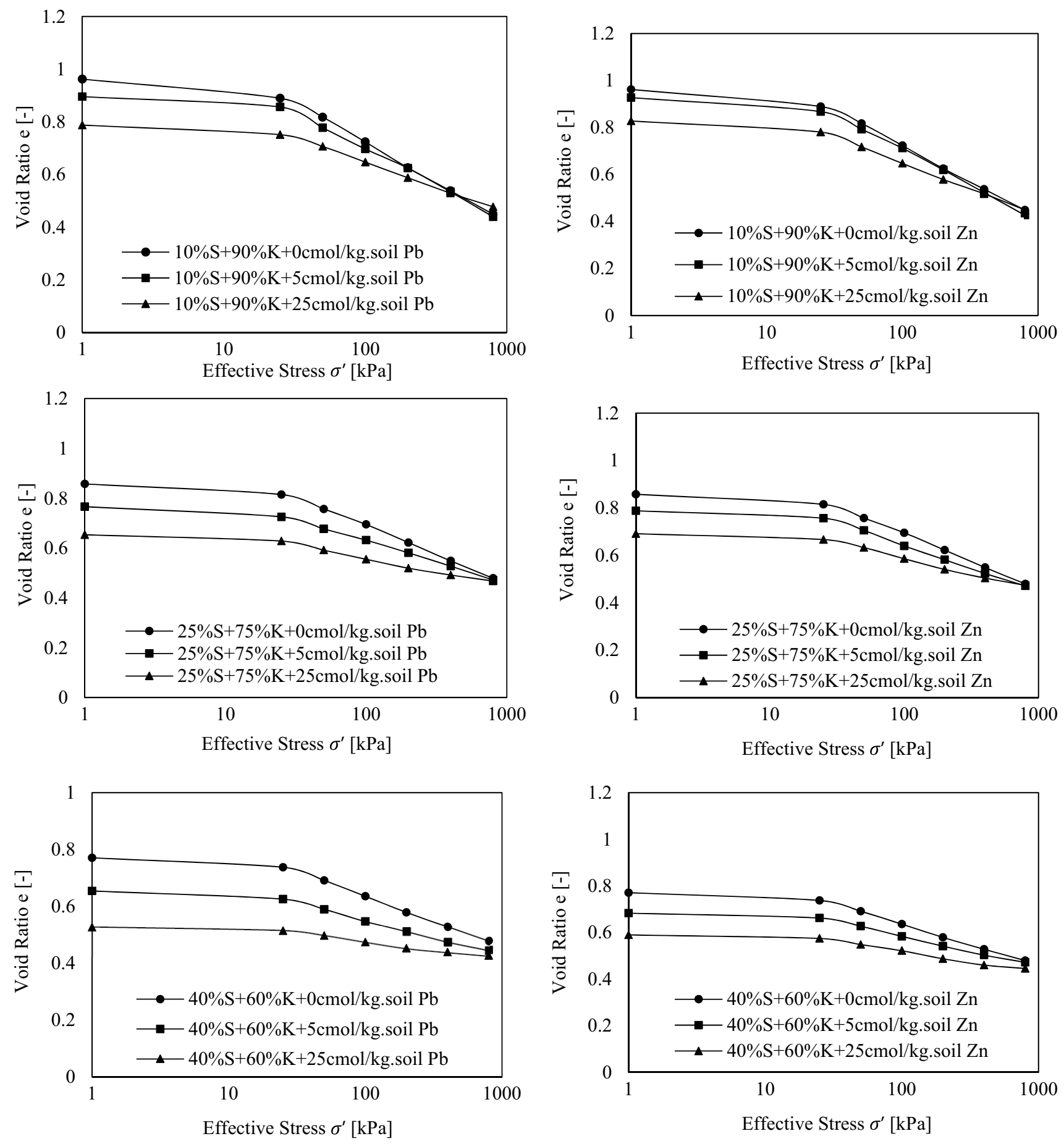

Fig. 12 Diagram of void ratio versus effective stress for kaolinite-sand samples at different concentration of $\mathrm{Pb}$ (II) and $\mathrm{Zn}$ (II)

be due to the selective adsorption and higher tendency of kaolinite in adsorption of $\mathrm{Pb}$ (II) relative to $\mathrm{Zn}$ (II).

The direct shear test was performed in order to evaluate samples shear strength parameters. Normal and sear force and shear displacement were measured. Normal and shear stress and the shear strain were calculated based on the obtained results and sample dimensions.
Shear strength parameters were determined by a diagram of shear stress versus normal stress. Figures 14 and 15 represent the changes in the cohesion of kaolinite-sand mixture samples with different percentages of sand at the presence of $\mathrm{Pb}(\mathrm{II})$ and $\mathrm{Zn}(\mathrm{II})$.

Figures 14 and 15 demonstrate that in all three types of soil (kaolinite-sand mixture samples with different sand 


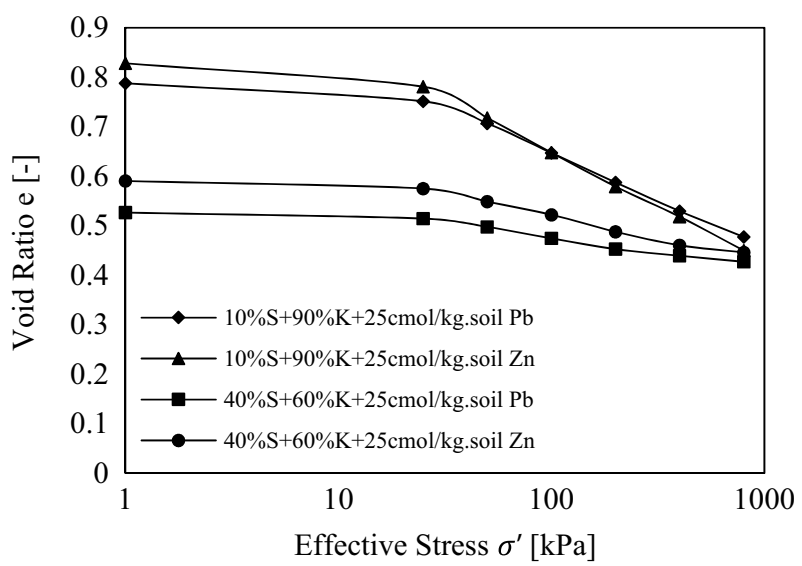

Fig. 13 Comparison of $\mathrm{Pb}(\mathrm{II})$ and $\mathrm{Zn}$ (II) impact of consolidation behavior of kaolinite-sand mixtures

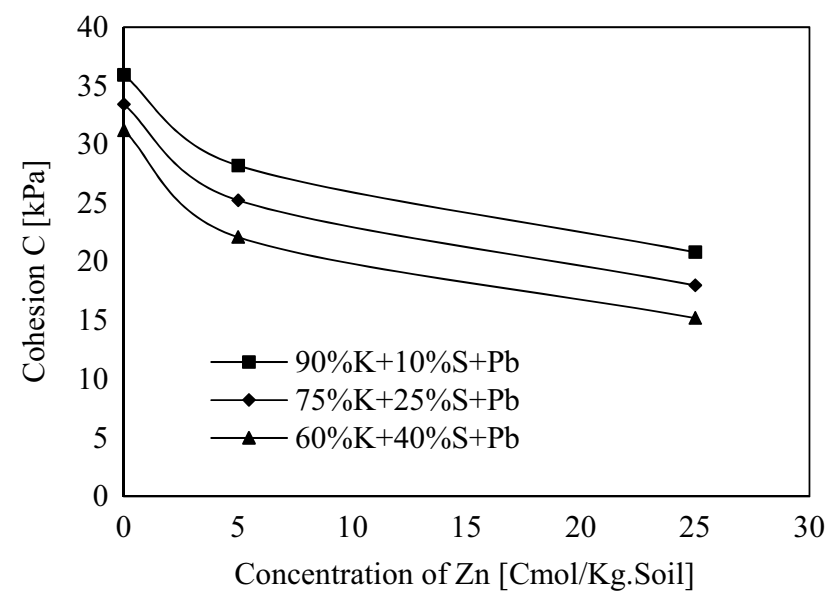

Fig. 14 Cohesion of kaolinite-sand mixture samples with different sand percentages at the presence of $\mathrm{Pb}(\mathrm{II})$ in the direct shear test [41]

percentages) with the increase in the concentration of both contaminants, soil cohesion has decreased [41].

The results are consistent with the results of the research by Yong et al. [57]. They discussed that absorption of bivalent capacitances such as $\mathrm{Pb}(\mathrm{II}), \mathrm{Zn}(\mathrm{II})$, and $\mathrm{Cd}(\mathrm{II})$ by kaolinite reduced the thickness of the doped layer, resulting in reduced repulsive forces and integrated structure. Accordingly, when kaolinite is placed against a two-capacity metal contaminant, its shear strength decreases [57].

Moreover, Figs. 16 and 17 indicate the changes in the friction angle of kaolinite-sand mixture with different sand percentages in the presence of different concentrations of $\mathrm{Pb}$ (II) and $\mathrm{Zn}$ (II) contaminants [41].

The results obtained from Figs. 16 and 17 suggest that the presence of both contaminants has had a very little

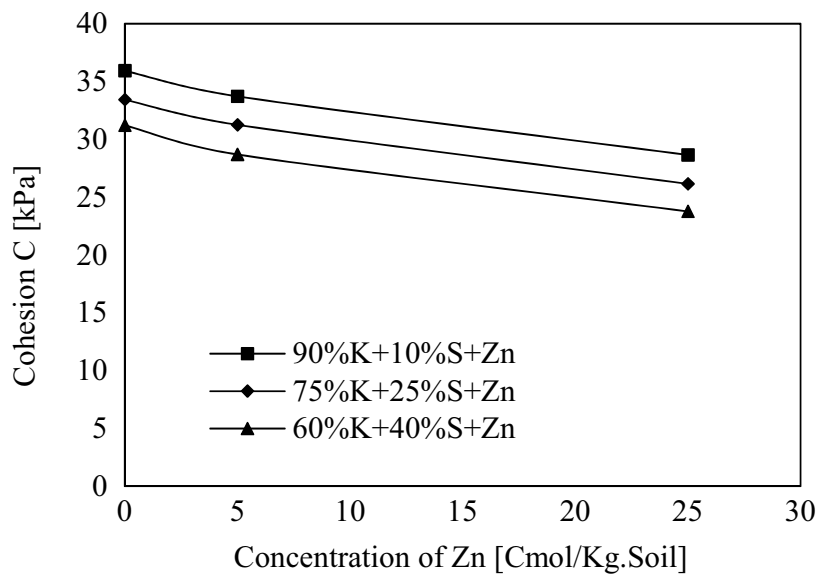

Fig. 15 The changes in the cohesion of kaolinite-sand mixture samples with different sand percentages at the presence of $\mathrm{Zn}$ (II) in the direct shear test [41]

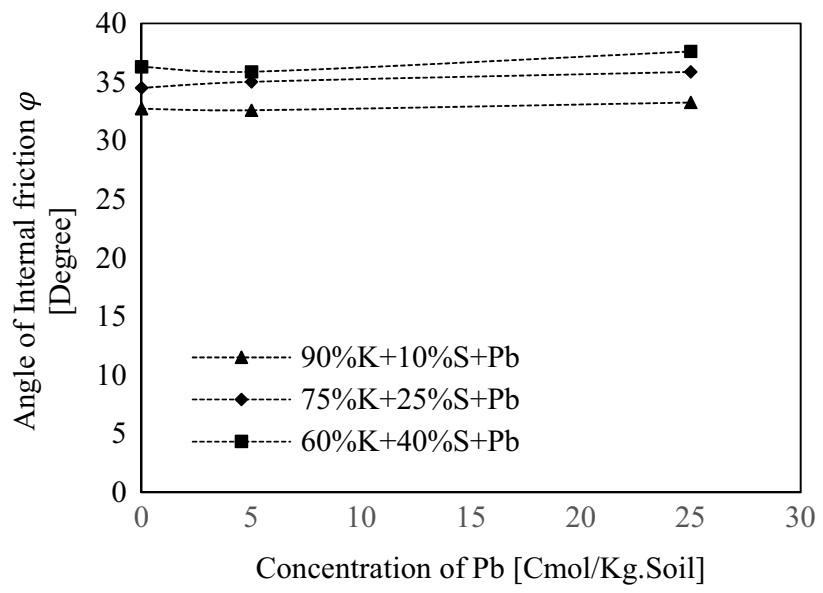

Fig. 16 Internal friction angle of kaolinite-sand mixture samples versus different sand percentages of $\mathrm{Pb}(\mathrm{II})$ in the direct shear test [41]

effect on the internal friction angle of the samples, such that for addition of $25 \mathrm{cmol} / \mathrm{kg}$-soil of $\mathrm{Pb}$ (II) and $\mathrm{Zn}$ (II) in the kaolinite $90 \%$-sand $10 \%$ mixture, the internal friction angle of the samples has increased by only 2 and 3\%, respectively [41]. This implies an insignificant effect of heavy-metal contaminants on the internal friction angle of kaolinite-sand mixtures. In other words, as the internal friction angle of kaolinite-sand mixture is dependent on the ratio of sand and heavy-metal contaminants have no effect on the sand, the internal friction angle of the kaolinite-sand mixture has not been influenced by the presence of heavy-metal contaminants. Further, this very trivial increase in the internal friction angle of the samples can be attributed to the 


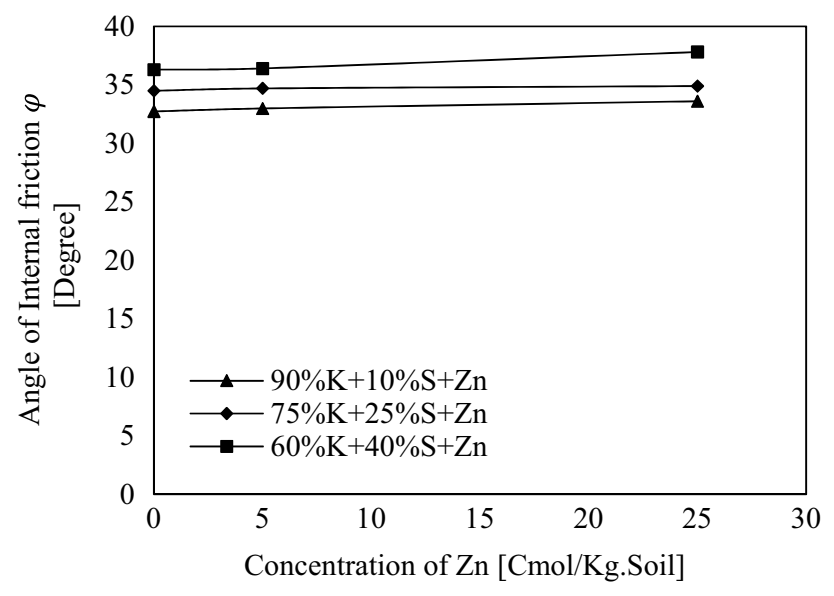

Fig. 17 Internal friction angle of kaolinite-sand mixture samples versus different sand percentages of $\mathrm{Zn}(\mathrm{II})$ in the direct shear test [41]

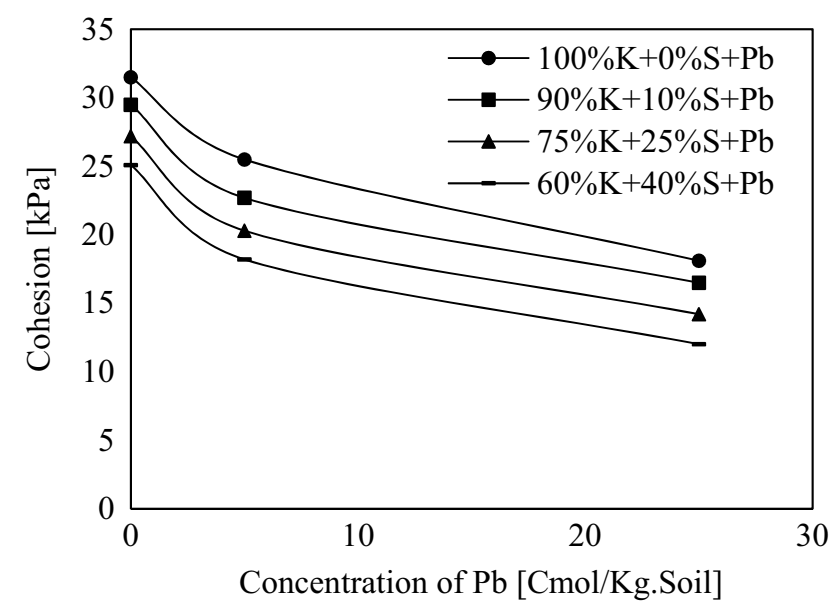

Fig. 18 Cohesion of kaolinite-sand mixture samples with different sand percentages at the presence of $\mathrm{Pb}(\mathrm{II})$ in the unconfined compression test

flocculation of the structure of the clay due to these contaminants.

The unconfined compression test results is presented in Figs. 18 and 19 for pure kaolinite and its mixture with sand in the presence of heavy metal. As It was observed form the direct shear test the cohesion decrease with the increase of sand content. The percent of reduction was about $20 \%$ when there were no contamination. With the increase of $\mathrm{Pb}$ (II) from 0 to $25 \mathrm{cmol} / \mathrm{kg}$-soil the reduction of cohesion reach to $42,44,48$ and $52 \%$ for the ratio of pure kaolinite, $90 \% \mathrm{~K}, 75 \%$ Kand $40 \% \mathrm{~K}$, respectively.

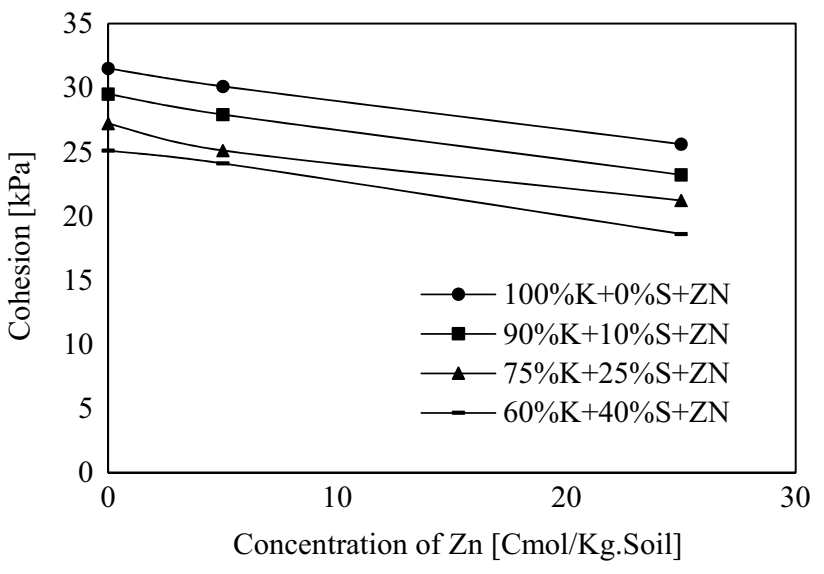

Fig. 19 The changes in the cohesion of kaolinite-sand mixture samples with different sand percentages at the presence of $\mathrm{Zn}(\mathrm{II})$ in the unconfined compression test

\section{Conclusion}

As mentioned, wide studies have been conducted in order to evaluate the influence of heavy metal contaminants on geotechnical properties of clay and clay-sand mixtures. However, few studies considered the alteration of these parameters in kaolinite-sand mixes contaminated with heavy metals.

The present study evaluated changes of shear strength, sedimentation and permeability of heavy metal contaminated sandy clay through the direct shear test, consolidation test, Atterberge limits, and sedimentation test.

The results of this research can be summarized as follows:

(a) The results of XRD and sedimentation experiments indicate that the presence of $\mathrm{Pb}(\mathrm{II})$ and $\mathrm{Zn}(\mathrm{II})$ to the reduction of the thickness of the double-layer in clay loess and the overcoming of gravity forces on repulsion between them, has transformed the structure from dispersed to fluctuated, and latter phenomena is also increased by increasing the concentration of heavy metal contaminants.

(b) The results obtained from investigation of retention of $\mathrm{Pb}(\mathrm{II})$ and $\mathrm{Zn}$ (II) suggest that across all the samples and in the presence of both heavy metal contaminants, with the increase in the concentration of contaminants, the retention capacity of kaolinitesand mixture samples has increased. Increase in the concentration of $\mathrm{Zn}$ (II) up to $25 \mathrm{cmol} / \mathrm{kg}$-soil, the kaolinite-sand mixture samples with sand percentages of 10,25 , and $40 \%$ showed an ability to retain around 20,22 , and $25 \mathrm{cmol} / \mathrm{kg}$-soil for $\mathrm{Zn}(\mathrm{II})$. 
However, the retention capacity for $\mathrm{Pb}$ (II) for those samples has been 24,26 , and $29 \mathrm{cmol} / \mathrm{kg}$-soil.

(c) The liquid limit of the samples has decreased in the presence of both $\mathrm{Pb}(\mathrm{II})$ and $\mathrm{Zn}(\mathrm{II})$ and a further reduction was observed as their concentration increased. Further, the results obtained from the experiments suggest that at higher concentrations of contaminants, the reduction rate of the liquid limit of the samples declines with the increase in sand percentage. In other words, in the presence of a contaminant with a higher concentration, the degree of influence of sand percentage changes has also declined on the liquid limit of samples.

(d) Consolidation curve of contaminated kaolinite-sand mixtures showed that as contaminate concentration increases, void ratio and settlement of samples decreases. Increase of $\mathrm{Pb}$ (II) concentration from 0 to $25 \mathrm{cmol} / \mathrm{kg}$-soil, void ratio of kaolinite-sand samples containing 10, 25 and $40 \%$ sand declined by 18,24 and $32 \%$, respectively. The reduction values for $\mathrm{Zn}$ (II) were 14,19 and $23 \%$. Results also indicated that $\mathrm{Pb}$ (II) was more influential than $\mathrm{Zn}$ (II) that due to the selective adsorption and higher tendency of kaolinite in adsorbing $\mathrm{Pb}(\mathrm{II})$.

(e) The results obtained from the direct shear experiment suggest that in all three soil samples (kaolinite-sand mixture samples with different sand percentages), the increase in the concentration of both contaminants lead nitrate $s$ to a decrease in soil cohesion. The difference between the reduction rate of cohesion of kaolinite-sand mixture samples in the presence of $\mathrm{Pb}$ (II) and $\mathrm{Zn}$ (II) can be attributed to the selective adsorption process and ability of sedimentation in the interaction between soil and contamination. Moreover, since the internal friction angle of the kaolinite-sand mixture dependent on sand ratio and presence of heavy metal contaminants has no effect on the sand, therefore, the internal friction angle of the kaolinite-sand mixture has not been affected by the presence of heavy metal contaminants. In order to measure the cohesion unconfined compression tests were performed on samples. The cohesion are approximately equal to the results obtained from the direct shear test. The results of this research can be used as an initial information for predicting the behavior of kaolinite which is exposed to the heavy metal.

Acknowledgements The authors thank University Mohaghegh Ardabili for Funding and providing laboratory equipment for performing this research.

\section{Compliance with ethical standards}

Conflict of interest The authors declare that they have no conflict of interest.

\section{References}

1. Hanfi MY, Mostafa MY, Zhukovsky MV (2020) Heavy metal contamination in urban surface sediments: sources, distribution, contamination control, and remediation. Environ Monit Assess 192(1):32

2. Sun Y, Zhou Q, Xie X, Liu R (2010) Spatial, sources and risk assessment of heavy metal contamination of urban soils in typical regions of Shenyang, China. J Hazard Mater 174(1-3):455-462

3. Yong RN (2000) Geoenvironmental engineering: contaminated soils, pollutant fate, and mitigation. CRC Press, Boca Raton

4. Bagchi A (1987) Natural attenuation mechanisms of landfill leachate and effects of various factors on the mechanisms. Waste Manage Res 5(4):453-463

5. Schoonheydt RA, Johnston CT (2006) Surface and interface chemistry of clay minerals. Dev Clay Sci 1:87-113

6. Arasan S (2010) Effect of chemicals on geotechnical properties of clay liners: a review. Research Journal of Applied Sciences, Engineering and Technology 2(8):765-775

7. Daka MR (2015) Geotechnical properties of oil contaminated soil

8. Khosravi E, Ghasemzadeh H, Sabour MR, Yazdani H (2013) Geotechnical properties of gas oil-contaminated kaolinite. Eng Geol 166:11-16

9. Reddy KR, Hettiarachchi H, Gangathulasi J, Bogner JE (2011) Geotechnical properties of municipal solid waste at different phases of biodegradation. Waste Manag 31(11):2275-2286

10. Zhu F, Li Z, Dong W, Ou Y (2019) Geotechnical properties and microstructure of lime-stabilized silt clay. Bull Eng Geol Environ 78(4):2345-2354

11. Karkush MO, Ali SD (2019) Effects of copper sulfate contamination on the geotechnical behavior of clayey soils. J GeoEng 14(1):47-52

12. Sridharan A, Jayadeva M (1982) Double layer theory and compressibility of clays. Geotechnique 32(2):133-144

13. Ouhadi V, Hamidi S, Amiri M (2016) Impact of heavy metal contaminants on coefficient of variations of compression index, expansion index and permeability coefficient of bentonite from micro-structural point of view

14. Soga K, Mitchell J (2005) Fundamentals of soil behavior. Wiley, Hoboken

15. Abollino $O$, Aceto $M$, Malandrino $M$, Sarzanini $C$, Mentasti $E$ (2003) Adsorption of heavy metals on Na-montmorillonite. Effect of $\mathrm{pH}$ and organic substances. Water Res 37(7):1619-1627

16. Baun DL, Christensen TH (2004) Speciation of heavy metals in landfill leachate: a review. Waste Manage Res 22(1):3-23

17. Bellir K, Bencheikh-Lehocine M, Meniai A-H, Gherbi N (2005) Study of the retention of heavy metals by natural material used as liners in landfills. Desalination 185(1-3):111-119

18. Davies B (1997) Heavy metal contaminated soils in an old industrial area of Wales, Great Britain: source identification through statistical data interpretation. Water Air Soil Pollut 94(1):85-98

19. He Y, Li BB, Zhang KN, Li Z, Chen YG, Ye WM (2019) Experimental and numerical study on heavy metal contaminant migration and retention behavior of engineered barrier in tailings pond. Environ Pollut 252:1010-1018

20. Ohadi V, Amiri M, Ohadi M (2015) Micro-structural evaluation of lead heavy metal retention in stabilization and solidification 
with bentonite and cement. J Eng Geol 9(1):2575-2592. https ://doi.org/10.18869/acadpub.jeg.9.1.2575

21. Ouhadi V, Amiri M (2011) Geo-environmental behaviour of nanoclays in interaction with heavy metals contaminant. Amirkabir J Civ 42:29-36

22. Xia W-Y, Du Y-J, Li F-S, Li C-P, Yan X-L, Arulrajah A, Wang F, Song D-J (2019) In-situ solidification/stabilization of heavy metals contaminated site soil using a dry jet mixing method and new hydroxyapatite based binder. J Hazard Mater 369:353-361

23. Yu K, Xu J, Jiang X, Liu C, McCall W, Lu J (2017) Stabilization of heavy metals in soil using two organo-bentonites. Chemosphere 184:884-891

24. Zhang Z, Chen Y, Fang J, Guo F (2019) Study on shear behavior of kaolinite contaminated by heavy metal Cu (II). Environ Sci Pollut Res 26:1-8

25. Miranda-Trevino JC, Coles CA (2003) Kaolinite properties, structure and influence of metal retention on $\mathrm{pH}$. Appl Clay Sci 23(1-4):133-139

26. Olu-Owolabi BI, Alabi AH, Diagboya PN, Unuabonah El, Düring R-A (2017) Adsorptive removal of 2, 4, 6-trichlorophenol in aqueous solution using calcined kaolinite-biomass composites. J Environ Manage 192:94-99

27. Fang H-Y, Daniels JL (2006) Introductory geotechnical engineering: an environmental perspective. CRC Press, Boca Raton

28. Lo IM, Luk AF, Yang X (2004) Migration of heavy metals in saturated sand and bentonite/soil admixture. J Environ Eng 130(8):906-909

29. Sivapullaiah PV (2005) Kaolinite-alkali interaction and effects on basic properties. Geotech Geol Eng 23(5):601-614

30. Karkush MO, Zaboon AT, Hussien HM (2013) Studying the effects of contamination on the geotechnical properties of clayey soil. In: Coupled phenomena in environmental geotechnics. Taylor \& Francis Group, London, pp 599-607

31. Karkush MO, Ali SD (2020) Impacts of lead nitrate contamination on the geotechnical properties of clayey soil. J Eng Sci Technol 15(2):1032-1045

32. Jiang $M-q$, Jin X-y, Lu X-Q, Chen Z-I (2010) Adsorption of Pb(II), $\mathrm{Cd}$ (II), Ni (II) and Cu (II) onto natural kaolinite clay. Desalination 252(1-3):33-39

33. Akcanca F, Aytekin M (2014) Impact of wetting-drying cycles on the hydraulic conductivity of liners made of lime-stabilized sand-bentonite mixtures for sanitary landfills. Environ Earth Sci 72(1):59-66

34. Alonso E, Romero E, Hoffmann C, García-Escudero E (2005) Expansive bentonite-sand mixtures in cyclic controlled-suction drying and wetting. Eng Geol 81(3):213-226

35. Ballarini E, Graupner B, Bauer S (2017) Thermal-hydraulicmechanical behavior of bentonite and sand-bentonite materials as seal for a nuclear waste repository: numerical simulation of column experiments. Appl Clay Sci 135:289-299

36. Pakbaz MS, Moqaddam AS (2012) Effect of sand gradation on the behavior of sand-clay mixtures. Int J Geomate 3(1):325-331

37. Ouhadi V, Haghayegh A, Bayesteh H (2008) Effect of heavy metal contaminants on the performance of sand enhanced bentonite (SEB) in engineering waste disposal sites

38. Olgun M, Yildiz M (2012) The effects of pore fluids with different dielectric constants on the geotechnical behaviour of kaolinite. Arab J Sci Eng 37:1-16

39. Obut A (2005) Sedimentation characteristics of kaolin and bentonite in concentrated solutions. Acta Montanistica Slovaca 10(1):145-150

40. Kang X, Zhao X, Bate B (2013) Sedimentation behavior of fly ash-kaolinite mixtures

41. Negahdar A, Shabanian M, NikGhalbPour M (2017) The effect of heavy metal contaminants on the shear strength parameters of sandy clay. Amirkabir J Civ Eng. https://doi.org/10.22060/ ceej.2017.12869.5287

42. Chen Y, Meehan CL (2011) Undrained strength characteristics of compacted bentonite/sand mixtures. In: ASCE Proceedings of the geo-frontiers 2011 conference, 13-16 March 2011, Dallas, TX|d 20110000. American Society of Civil Engineers, Reston, VA

43. Haddad SA, Ahmed MMM, El-Azeim MMA Growth, enzymes and microbial activities of two leguminous plants grown on soils contaminated with heavy metals

44. Anandarajah A, Zhao D (2000) Triaxial behavior of kaolinite in different pore fluids. J Geotech Geoenviron Eng 126(2):148-156

45. Cheshmazar E, Arfaeinia H, Karimyan K, Sharafi H, Hashemi SE (2018) Dataset for effect comparison of irrigation by wastewater and ground water on amount of heavy metals in soil and vegetables: accumulation, transfer factor and health risk assessment. Data Brief 18:1702-1710

46. Ouhadi VR, Bahadori Nezhad OR, Amiri M (2014) Lead retention of carbonated kaolinite in the adsorption and electrokinetics processes. Modares Civ Eng J (MCEJ) 14:1-15

47. Standard A (2004) Annual book of ASTM standards. American Society for Testing and Materials Annual, Philadelphia, PA, 4 (04.08)

48. Hendershot WH, Duquette M (1986) A simple barium chloride method for determining cation exchange capacity and exchangeable cations 1. Soil Sci Soc Am J 50(3):605-608

49. Moore DM, Reynolds RC Jr (1989) X-ray diffraction and the identification and analysis of clay minerals. Oxford University Press (OUP), Oxford

50. Ouhadi V, Yong R (2003) Experimental and theoretical evaluation of impact of clay microstructure on the quantitative mineral evaluation by XRD analysis. Appl Clay Sci 23(1-4):141-148

51. Hesse PR (1971) A textbook of soil chemical analysis

52. Ouhadi V, Yong R, Sedighi M (2006) Influence of heavy metal contaminants at variable $\mathrm{pH}$ regimes on rheological behaviour of bentonite. Appl Clay Sci 32(3):217-231

53. Zhou X, Liu D, Bu H, Deng L, Liu H, Yuan P, Du P, Song H (2018) XRD-based quantitative analysis of clay minerals using reference intensity ratios, mineral intensity factors, Rietveld, and full pattern summation methods: a critical review. Solid Earth Sci 3(1):16-29

54. Ouhadi V, Choobchian S (2011) Influence of cation valence and concentration on the results of X-Ray analysis for smectite clay mineral. Iran J Crystallogr Mineral 19(2):271-280

55. Kaya A, Ören AH, Yükselen Y (2006) Settling of kaolinite in different aqueous environment. Mar Georesour Geotechnol 24(3):203-218

56. LaConde K (1983) Process design manual for land application of municipal sludge. US Environmental Protection Agency, Center for Environmental Research

57. Yong RN, Mohamed A-MO, Warkentin BP (1992) Principles of contaminant transport in soils. Elsevier, Amsterdam

58. Ouhadi V, Yong R, Rafiee F, Goodarzi A (2011) Impact of carbonate and heavy metals on micro-structural variations of clayey soils. Appl Clay Sci 52(3):228-234

59. Chen J, Anandarajah A, Inyang H (2000) Pore fluid properties and compressibility of kaolinite. J Geotech Geoenviron Eng 126(9):798-807

60. Yarlagadda PS, Matsumoto MR, VanBenschoten JE, Kathuria A (1995) Characteristics of heavy metals in contaminated soils. J Environ Eng 121(4):276-286

Publisher's Note Springer Nature remains neutral with regard to jurisdictional claims in published maps and institutional affiliations. 